\title{
Urinary Sodium-to-Potassium Ratio Tracks the Changes in Salt Intake during an Experimental Feeding Study Using Standardized Low-Salt and High-Salt Meals among Healthy Japanese Volunteers
}

\author{
Midori Sasaki Yatabe 1,2,3, Toshiyuki Iwahori ${ }^{4,5}$ (i), Ami Watanabe ${ }^{1}$, Kozue Takano ${ }^{1}$, \\ Hironobu Sanada ${ }^{2}$, Tsuyoshi Watanabe ${ }^{2}$ (i), Atsuhiro Ichihara ${ }^{3}$, Robin A. Felder ${ }^{6}$, \\ Katsuyuki Miura ${ }^{5,7}$, Hirotsugu Ueshima ${ }^{5,7}$, Junko Kimura ${ }^{1}$ and Junichi Yatabe ${ }^{1,2,3, *}$ \\ 1 Department of Pharmacology, Fukushima Medical University School of Medicine, Fukushima 960-1295, \\ Japan; midorisy@endm.twmu.ac.jp (M.S.Y.); amichacha3@gmail.com (A.W.); takak1209@gmail.com (K.T.) \\ 2 Department of Nephrology, Hypertension, Diabetology, Endocrinology and Metabolism, \\ Fukushima Medical University School of Medicine, Fukushima 960-1295, Japan; \\ sndmak2006@yahoo.co.jp (H.S.); twat0423@fmu.ac.jp (T.W.) \\ 3 Department of Medicine II, Endocrinology and Hypertension, Tokyo Women's Medical University, \\ Tokyo 162-8666, Japan; atzichi@endm.twmu.ac.jp \\ 4 Research and Development Department, Omron Healthcare Co., Ltd., Muko 617-0002, Japan; \\ iwahori@belle.shiga-med.ac.jp \\ 5 Department of Public Health, Shiga University of Medical Science, Shiga 520-2192, Japan; \\ miura@belle.shiga-med.ac.jp (K.M.); hueshima@belle.shiga-med.ac.jp (H.U.) \\ 6 Department of Pathology, University of Virginia Health System, Charlottesville, VA 22908, USA; \\ raf7k@virginia.edu \\ 7 Center for Epidemiologic Research in Asia, Shiga University of Medical Science, Shiga 520-2192, Japan \\ * Correspondence: jyatabe@endm.twmu.ac.jp; Tel.: +81-333-538-111
}

Received: 6 June 2017; Accepted: 25 August 2017; Published: 29 August 2017

\begin{abstract}
The $\mathrm{Na} / \mathrm{K}$ ratio is considered to be a useful index, the monitoring of which allows an effective Na reduction and $\mathrm{K}$ increase, because practical methods (self-monitoring devices and reliable individual estimates from spot urine) are available for assessing these levels in individuals. An intervention trial for lowering the $\mathrm{Na} / \mathrm{K}$ ratio has demonstrated that a reduction of the $\mathrm{Na} / \mathrm{K}$ ratio mainly involved Na reduction, with only a small change in $\mathrm{K}$. The present study aimed to clarify the relationship between dietary $\mathrm{Na}$ intake and the urinary $\mathrm{Na} / \mathrm{K}$ molar ratio, using standardized low- and high-salt diets, with an equal dietary $\mathrm{K}$ intake, to determine the corresponding $\mathrm{Na} / \mathrm{K}$ ratio. Fourteen healthy young adult volunteers ingested low-salt ( $3 \mathrm{~g}$ salt per day) and high-salt (20 g salt per day) meals for seven days each. Using a portable urinary $\mathrm{Na} / \mathrm{K}$ meter, participants measured their spot urine at each voiding, and 24-h urine was collected on the last day of each diet period. On the last day of the unrestricted, low-salt, and high-salt diet periods, the group averages of the 24-h urine $\mathrm{Na} / \mathrm{K}$ ratio were $4.2,1.0$, and 6.9 , while the group averages of the daily mean spot urine $\mathrm{Na} / \mathrm{K}$ ratio were $4.2,1.1$, and 6.6 , respectively. The urinary $\mathrm{Na} / \mathrm{K}$ ratio tracked changes in dietary salt intake, and reached a plateau approximately three days after each change in diet. Frequent monitoring of the spot urine $\mathrm{Na} / \mathrm{K}$ ratio may help individuals adhere to an appropriate dietary Na intake.
\end{abstract}

Keywords: dietary sodium intake; experimental feeding study; salt restriction; standardized diet; urinary sodium-to-potassium ratio 


\section{Introduction}

It has previously been demonstrated that excess dietary sodium $(\mathrm{Na})$ and insufficient dietary potassium (K) cause blood pressure (BP) elevation [1]. Additionally, epidemiological studies have demonstrated that high dietary $\mathrm{Na}$ and low dietary $\mathrm{K}$ intakes are also associated with increased cardiovascular disease (CVD) risks [2-5]. Despite rigorous campaigns to reduce $\mathrm{Na}$ and increase $\mathrm{K}$ intake, there remains a large discrepancy between the recommended and actual intakes of both $\mathrm{Na}$ and $\mathrm{K}$ [6-8]. Therefore, exact measurement methods are required to facilitate more accurate association studies between dietary salt intake and CVD risk, and avoid discrepant findings arising from technical issues [9,10]. However, the reliable measurement of individual $\mathrm{Na}$ and $\mathrm{K}$ intake values depends on high-quality, repeated 24-h urine collection (over a period of several days), which is inconvenient and expensive [10-14]. Methods using single spot urine sampling, which are considerably easier than repeated 24-h urine collection, to estimate urinary Na excretion over a single 24-h period have been proposed for the evaluation of population means [15-17], but these techniques have inherent problems in terms of accuracy $[10,18,19]$.

The $\mathrm{Na} / \mathrm{K}$ ratio is considered to be a useful index for use in achieving effective Na reduction and $\mathrm{K}$ increase [20]. Epidemiological studies have suggested that the urinary $\mathrm{Na} / \mathrm{K}$ ratio is a better measurement of dietary Na reduction and $\mathrm{K}$ increase in relation to BP and CVD risk assessments than separate Na or K levels [21-27]. Additionally, the former is easier to measure than the latter, due to its independence from urine collection and creatinine measurement; indeed, repeated $\mathrm{Na} / \mathrm{K}$ ratio measurements from spot urine samples provide more reliable estimates than those from 24-h urine samples [28-30]. Previous studies have demonstrated that single spot urine samples can be used to estimate the population mean values of the 24-h urine $\mathrm{Na} / \mathrm{K}$ ratio [28], and that four to seven repeated measurements of the $\mathrm{Na} / \mathrm{K}$ ratio in spot urine samples can be used to estimate the $24-\mathrm{h}$ urine $\mathrm{Na} / \mathrm{K}$ ratio in individuals $[29,30]$. Moreover, a recent report on the self-monitoring of the $\mathrm{Na} / \mathrm{K}$ ratio for both $\mathrm{Na}$ reduction and $\mathrm{K}$ increase has emphasized that an individual approach can be used; reduction of the $\mathrm{Na} / \mathrm{K}$ ratio mainly involved $\mathrm{Na}$ reduction, while $\mathrm{K}$ only changed a little in healthy volunteers recruited from the general population [31].

Although there are separate dietary recommendations for $\mathrm{Na}$ and $\mathrm{K}$, currently, no generally accepted target urinary $\mathrm{Na} / \mathrm{K}$ ratio level has been established [20]. A recent report speculated that a rough estimate of the mean salt intake ( $\mathrm{g} /$ day) of a population may be derived by calculating approximately two to four times the population mean $24-\mathrm{h}$ urinary $\mathrm{Na} / \mathrm{K}$ molar ratio in different populations [20]. However, the urinary $\mathrm{Na} / \mathrm{K}$ ratio levels that correspond to particular $\mathrm{Na}$ or $\mathrm{K}$ excretion or dietary intake levels have not yet been determined. Additionally, $\mathrm{Na}$ and $\mathrm{K}$ are excreted through different pathways [13], and the time lapse observed between $\mathrm{Na}$ and $\mathrm{K}$ intake and their excretion, reflected as the $\mathrm{Na} / \mathrm{K}$ ratio, remains unknown. Once this is known, the urinary $\mathrm{Na} / \mathrm{K}$ ratio may be a useful index to monitor when targeting effective $\mathrm{Na}$ reduction and $\mathrm{K}$ increase [20].

Therefore, we performed this experimental dietary study with the aim of determining a recommended cutoff value for the $\mathrm{Na} / \mathrm{K}$ ratio for practical salt reduction by monitoring daily $\mathrm{Na} / \mathrm{K}$ ratios. To this end, we sought to clarify the urinary $\mathrm{Na} / \mathrm{K}$ ratio corresponding to dietary $\mathrm{Na}$ and $\mathrm{K}$ intake, and to examine the daily changes in the urinary $\mathrm{Na} / \mathrm{K}$ ratio after an abrupt change in $\mathrm{Na}$ intake, using standardized meals.

\section{Materials and Methods}

\subsection{Participants}

The participants were healthy volunteers without hypertension (defined as an office blood pressure exceeding 140/90 $\mathrm{mmHg}$, at baseline), diabetes, or other known diseases, and who were not taking regular medication. Sixteen individuals were recruited for the study. The study was conducted in accordance with the Declaration of Helsinki, and the Ethics Committee of Fukushima Medical 
University (Approval No. 1555; Approval Date, 22 Nov. 2012) approved the protocol. All participants provided written informed consent, and no adverse events associated with the study were recorded.

\subsection{Dietary Protocol}

The participants consumed a low-salt (LS) diet $(3 \mathrm{~g} /$ day sodium chloride $(\mathrm{NaCl})=51 \mathrm{mmol} /$ day $)$ for seven days, which was immediately followed by a high-salt (HS) diet $(20 \mathrm{~g} \mathrm{NaCl} /$ day $=342 \mathrm{mmol} /$ day $)$ for another seven days. The menu plan was designed by three registered dietitians. The mean dietary $\mathrm{K}$ intake reported among the Japanese population ranged from approximately 2.2 to $2.8 \mathrm{~g} /$ day $[32,33]$. Thus, we set the K amount to $2.5 \mathrm{~g} /$ day ( $64 \mathrm{mmol} /$ day) throughout the LS and HS diet periods. The K and protein intake amounts were standardized between the LS and HS diets, but the total energy intake was adjusted for each individual. The participants were allowed to consume low-Na, low-K snacks provided to them, but were instructed not to consume food outside of that provided by the study. The meals were cooked from scratch in the test kitchen in accordance with the menu plan. Moreover, all participants gathered in a dining hall for three meals a day during the entire period (both the LS and HS diet periods). Before the LS diet period, and again after the HS diet period, the participants followed their own regular, unrestricted (NS) diet under free-living conditions, without any restrictions on $\mathrm{Na}$ or $\mathrm{K}$ intake.

\subsection{Urinary Na/K Ratio and Blood Pressure Measurements}

The spot urinary $\mathrm{Na} / \mathrm{K}$ ratio was measured using a portable personal device throughout the study period (HEU-001-F; Omron Healthcare Co., Muko, Japan; Figure S1a,b) [31], which weighed about $50 \mathrm{~g}$. The device has flat iron electrodes that measure the urinary $\mathrm{Na} / \mathrm{K}$ ratio, and it displays the result within $1 \mathrm{~min}$. The participants were asked to measure and record their urinary $\mathrm{Na} / \mathrm{K}$ ratio at every voiding.

\subsection{Biochemical Analyses of Urine and Blood}

On the last day of each diet period, including the NS diet period before commencing the LS diet period, 24-h urine collections were conducted, in addition to spot urine $\mathrm{Na} / \mathrm{K}$ ratio measurements. Participants were instructed to collect all urine samples using a measuring cup, with all urine saved in $2 \mathrm{~L}$ bottles, unless urine collection was unsuccessful or contaminated with feces. To avoid underand overcollection, the start and end times of the 24-h urine collection were supervised by clinic staff. The 24-h urine collection began with the participants voiding urine to empty their bladder during the first visit and finished during the visit on the following day when the participants collected their urine in the bottles on-site and returned with their 24-h urine collection bottles. Urine was collected for $24 \mathrm{~h}$ and kept cold during the collection period. The samples were handled by certified staff. The $\mathrm{Na}, \mathrm{K}$, creatinine, and plasma aldosterone concentrations and plasma renin activity were determined in these samples, as described previously [34].

\subsection{Statistical Analysis}

\subsubsection{Dietary Intake vs. Urinary Excretion}

Participants obtained a fixed amount of dietary $\mathrm{Na}$ and $\mathrm{K}$ from the controlled meals provided during the study, and the $\mathrm{Na} / \mathrm{K}$ ratio, and $\mathrm{Na}$ and $\mathrm{K}$ excretions measured from the urine were compared in order to clarify the relationship between dietary $\mathrm{Na}$ intake and the urinary $\mathrm{Na} / \mathrm{K}$ molar ratio. All $p$ values were two-sided, and $p$ values $<0.05$ were considered to indicate statistically significant differences. Statistical analyses were performed using IBM SPSS Statistics (IBM Japan, Tokyo, Japan). The differences between the groups were analyzed using one-way repeated-measure analysis of variance with Bonferroni correction or the Friedman test, where applicable. Data are presented as mean \pm standard deviation (SD), unless otherwise noted. 
2.5.2. Daily Na/K ratio Assessment from Multiple Spot Urine Samples for Estimating the 24-h Urine $\mathrm{Na} / \mathrm{K}$ Ratio

Since participants were consuming a controlled diet in this study, the day-to-day variability of $\mathrm{Na}$ and $\mathrm{K}$ were expected to be minimized. Thus, we used a single $24-\mathrm{h}$ urine sample and daily repetitive measurements of the spot urine $\mathrm{Na} / \mathrm{K}$ ratio to evaluate the dietary levels of $\mathrm{Na}$ and $\mathrm{K}$ for each individual in this study. Iwahori et al. previously proposed repetitive measurements of the spot urine $\mathrm{Na} / \mathrm{K}$ ratio sampling from different days to estimate the seven-day $24-\mathrm{h} \mathrm{Na} / \mathrm{K}$ ratio [29,30]; however, daily repetitive spot urine $\mathrm{Na} / \mathrm{K}$ ratio sampling from the same day has not yet been established for estimating a single-day $24-\mathrm{h}$ urine $\mathrm{Na} / \mathrm{K}$ ratio under controlled dietary conditions. Thus, this estimation method was additionally evaluated in this study. Spearman's rho values for $\mathrm{Na} / \mathrm{K}$ ratios were calculated to examine the correlation between the daily mean values of the spot urine $\mathrm{Na} / \mathrm{K}$ ratio and the corresponding values for 24 -h urine specimens. Agreement between the daily mean values of the spot urine $\mathrm{Na} / \mathrm{K}$ ratio and the $24-\mathrm{h}$ urine $\mathrm{Na} / \mathrm{K}$ ratio was examined using the Bland-Altman method [35]. Bland-Altman plots showing the daily means of the spot urine $\mathrm{Na} / \mathrm{K}$ ratio and the $24-\mathrm{h}$ urine $\mathrm{Na} / \mathrm{K}$ ratio values versus the difference between these two values, were used to assess the mean difference (bias). The upper and lower agreement limits (mean difference $\pm 1.96 \times$ SD of difference) between the daily means of the spot urine $\mathrm{Na} / \mathrm{K}$ ratio and the $24-\mathrm{h}$ urine $\mathrm{Na} / \mathrm{K}$ ratio were calculated, as was the difference between the upper and lower agreement limits (defined as 95\% limit of the difference).

\section{Results}

\subsection{Baseline Parameters of the Participants}

Table 1 shows the baseline parameters of the participants on an unrestricted diet. We performed the study from January to February 2014. Excluding two participants who dropped out for personal reasons, 14 eligible individuals, comprising five men and nine women, aged 21 to 26 years, completed the study and their data were included in the final analysis.

Table 1. Baseline parameters of the participants on an unrestricted diet.

\begin{tabular}{ccc}
\hline Parameter & Unit & Mean \pm SD (Range) \\
\hline Men/women & & $5: 9=35.7 \%$ \\
Age & Years & $22.5 \pm 0.3(21-26)$ \\
Weight & $\mathrm{kg}$ & $53.3 \pm 5.1(44.9-63.1)$ \\
BMI & $\mathrm{kg} / \mathrm{m}^{2}$ & $20.4 \pm 2.0(17.2-25.6)$ \\
Fasting serum glucose & $\mathrm{mg} / \mathrm{dL}$ & $83 \pm 7$ \\
Insulin & $\mu \mathrm{IU} / \mathrm{mL}$ & $7.2 \pm 2.6$ \\
Morning pulse rate & Beats per min & $66 \pm 12$ \\
Evening pulse rate & Beats per min & $65 \pm 10$ \\
\hline
\end{tabular}

BMI, body mass index; SD, standard deviation.

\subsection{Changes in 24-h Urinary Na/K Ratio and Basic Parameters During the Study}

Data from urine samples with a low creatinine content $(<0.8 \mathrm{~g} /$ day or $<70 \%$ of maximal urinary creatinine excretion) were excluded from the analysis. The average urinary $\mathrm{Na} / \mathrm{K}$ molar ratios of the 14 participants, which was calculated from 24-h urine collection, were $4.2 \pm 1.9,1.0 \pm 0.3$, and $6.9 \pm 1.5$, (mean $\pm \mathrm{SD}$ ) on the last day of the NS, LS (3 g/day), and HS (20 g/day) diet periods, respectively. Their average dietary $\mathrm{NaCl}$ levels, based on urinary excretions calculated from 24 -h urine collection, were $7.3,1.7$, and $17.1 \mathrm{~g} /$ day for the NS, LS, and HS diet periods, respectively. Additionally, the urinary $\mathrm{K}$ excretion level was $1.16 \mathrm{~g} /$ day for the NS diet period. The $\mathrm{NaCl}$ excretion percentages, calculated based on Na excretion from 24-h urine for the LS and HS diet periods, were $57 \%$ and $86 \%$, respectively, of the designed dietary $\mathrm{NaCl}$ content of each respective diet. The urinary $\mathrm{K}$ excretion level increased by $33 \%$ during the HS diet period, even though a constant dietary K intake was maintained. Furthermore, 
the urinary $\mathrm{K}$ excretion percentages were $48 \%$ and $66 \%$ of the designed dietary $\mathrm{K}$ content for the LS and HS diets, respectively, under the assumption that $90 \%$ and $70 \%$ of dietary $\mathrm{Na}$ and $\mathrm{K}$, respectively, would be excreted in the urine.

No significant differences in blood pressure between the three diet periods were observed (Table 2). Hematocrit was significantly reduced during the HS diet period. Additionally, the urine volume increased by 1.5 -fold, but the plasma renin activity significantly decreased during the HS diet period as compared to the LS diet period.

Table 2. Parameters measured at the end of each diet period.

\begin{tabular}{cccccc}
\hline Parameter & Unit & Unrestricted & Low Salt & High Salt & $p$ Value \\
\hline Morning SBP & $\mathrm{mmHg}$ & $104 \pm 9$ & $103 \pm 7$ & $102 \pm 11$ & 0.769 \\
Morning DBP & $\mathrm{mmHg}$ & $69 \pm 7$ & $65 \pm 8$ & $70 \pm 7$ & 0.102 \\
Morning MBP & $\mathrm{mmHg}$ & $76 \pm 15$ & $78 \pm 7$ & $81 \pm 7$ & 0.341 \\
Morning pulse rate & $/ \mathrm{min}$ & $66 \pm 12$ & $67 \pm 13$ & $64 \pm 9$ & 0.652 \\
Hematocrit & $\%$ & $44.3 \pm 3.3$ & $44.4 \pm 3.9$ & $42.7 \pm 3.0^{*}$ & 0.045 \\
PAC & $\mathrm{pg} / \mathrm{mL}$ & $208 \pm 97$ & $391 \pm 204^{\$}$ & $133 \pm 63^{*, \#}$ & 0.001 \\
PRA & $\mathrm{ng} / \mathrm{mL} / \mathrm{h}$ & $1.3 \pm 1.1$ & $2.9 \pm 1.5^{\$}$ & $1.0 \pm 1.4^{*}$ & 0.006 \\
Creatinine & $\mathrm{mg} / \mathrm{dL}$ & $0.69 \pm 0.13$ & $0.71 \pm 0.14$ & $0.65 \pm 0.11^{*} \#$ & 0.000 \\
Serum Na & $\mathrm{mEq} / \mathrm{L}$ & $141 \pm 2$ & $141 \pm 1$ & $141 \pm 2$ & 0.220 \\
Serum K & $\mathrm{mEq} / \mathrm{L}$ & $4.0 \pm 0.2$ & $4.0 \pm 0.2$ & $4.1 \pm 0.3$ & 0.940 \\
Urine volume & $\mathrm{mL} / \mathrm{day}$ & $926 \pm 369$ & $978 \pm 336$ & $1416 \pm 495^{*} \#$ & 0.016 \\
Urine Na & $\mathrm{mmol} / \mathrm{day}$ & $128 \pm 47$ & $30 \pm 7 \$$ & $281 \pm 42^{*} \#$ & 0.001 \\
Urine K & $\mathrm{mmol} / \mathrm{day}$ & $32.3 \pm 9.4$ & $29.5 \pm 6.0$ & $39.2 \pm 7.6^{*}$ & 0.032 \\
Urine creatinine & $\mathrm{g} / \mathrm{day}$ & $1.20 \pm 0.25$ & $1.14 \pm 0.20$ & $1.23 \pm 0.29$ & 0.093 \\
Morning SBP & $\mathrm{mmHg}$ & $104 \pm 9$ & $103 \pm 7$ & $102 \pm 11$ & 0.769 \\
Morning DBP & $\mathrm{mmHg}$ & $69 \pm 7$ & $65 \pm 8$ & $70 \pm 7$ & 0.102 \\
\hline
\end{tabular}

SBP, systolic blood pressure; DBP, diastolic blood pressure; MBP, mean blood pressure; PAC, plasma aldosterone; PRA, plasma renin activity. Mean $\pm \mathrm{SD}$. For urinary data, those with urinary creatinine excretion of $<0.8 \mathrm{~g} /$ day or $<70 \%$ of the maximal urinary creatinine excretion were excluded from the analysis $(n=11-12) .{ }^{\$} p<0.05$ for unrestricted versus low-salt diet. ${ }^{*} p<0.05$ for low-salt versus high-salt diet. ${ }^{\#} p<0.05$ for unrestricted versus high-salt diet.

\subsection{Changes in Self-Measured Urinary Na/K Ratio During the Study}

In this study, the group means of the urinary $\mathrm{Na} / \mathrm{K}$ ratio obtained from the daily mean of repetitive spot urine $\mathrm{Na} / \mathrm{K}$ ratio determinations were $4.2 \pm 2.1,1.1 \pm 0.8$, and $6.6 \pm 2.1$ (mean $\pm \mathrm{SD}$ ) on the last day of the NS, LS (3 g/day), and HS (20 g/day) diet periods, respectively. The individual spot urine $\mathrm{Na} / \mathrm{K}$ ratio fluctuated under the controlled diets, with the variation being large during the HS diet period, but small during the LS diet period (Figure 1a). Diurnal variation was readily observed in most participants during the HS diet period. The group average urinary $\mathrm{Na} / \mathrm{K}$ ratio clearly showed a plateau approximately three days after the change in the dietary Na level (Figure 1b). In individual traces, the time to reaching the plateau varied between three and four days (Figure 1a).

The daily mean range of the device-measured individual urinary $\mathrm{Na} / \mathrm{K}$ molar ratio was narrow during the LS diet period (0.23-2.80), but wide during the HS diet period (3.16-10.14). In fact, $74 \%$ and $94 \%$ of the 207 individual-based urinary $\mathrm{Na} / \mathrm{K}$ molar ratio measurements taken during days four to seven of the LS diet were $\leq 1.0$ and $\leq 2.0$, respectively. During the last four days of the HS diet, $7.6 \%, 42.6 \%, 31.4 \%, 29.4 \%$, and $15.2 \%$ of the 278 individual-based urinary $\mathrm{Na} / \mathrm{K}$ molar ratio measurements were $\leq 4.0,4.1-6.0,6.1-8.0,8.1-10.0$, and $>10$, respectively. 

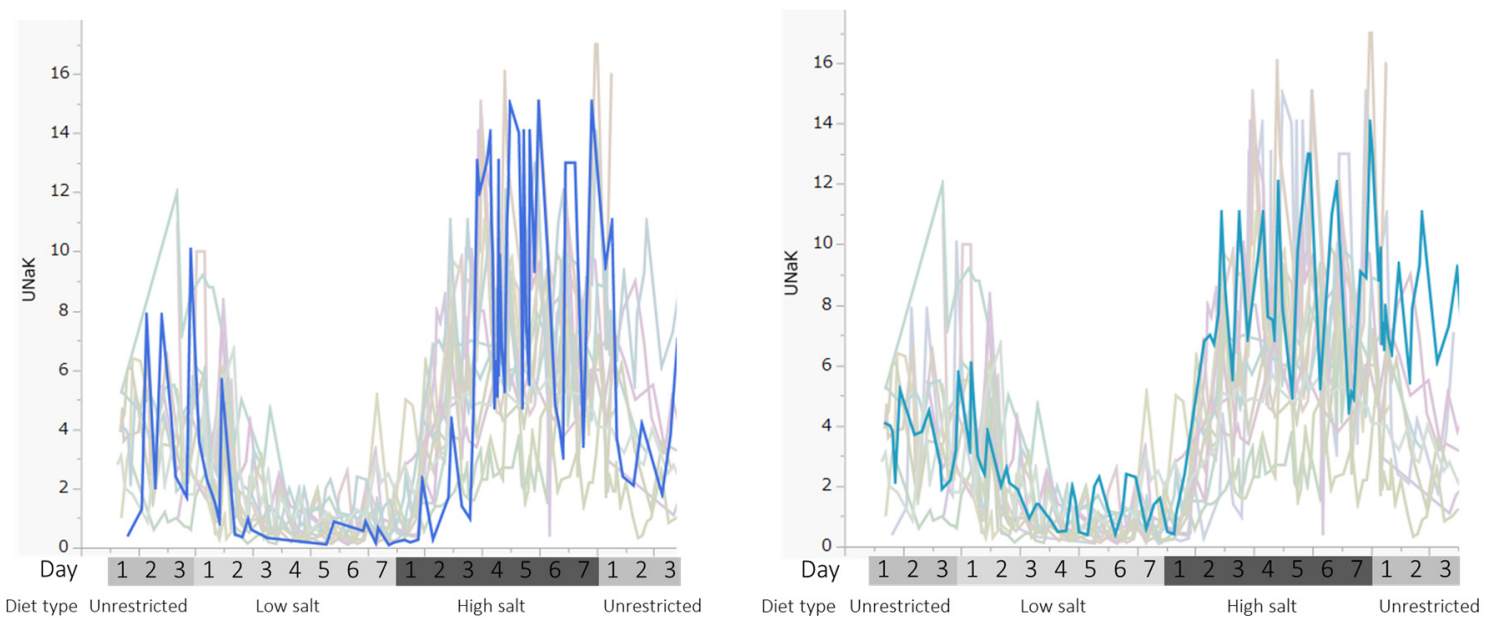

(a)

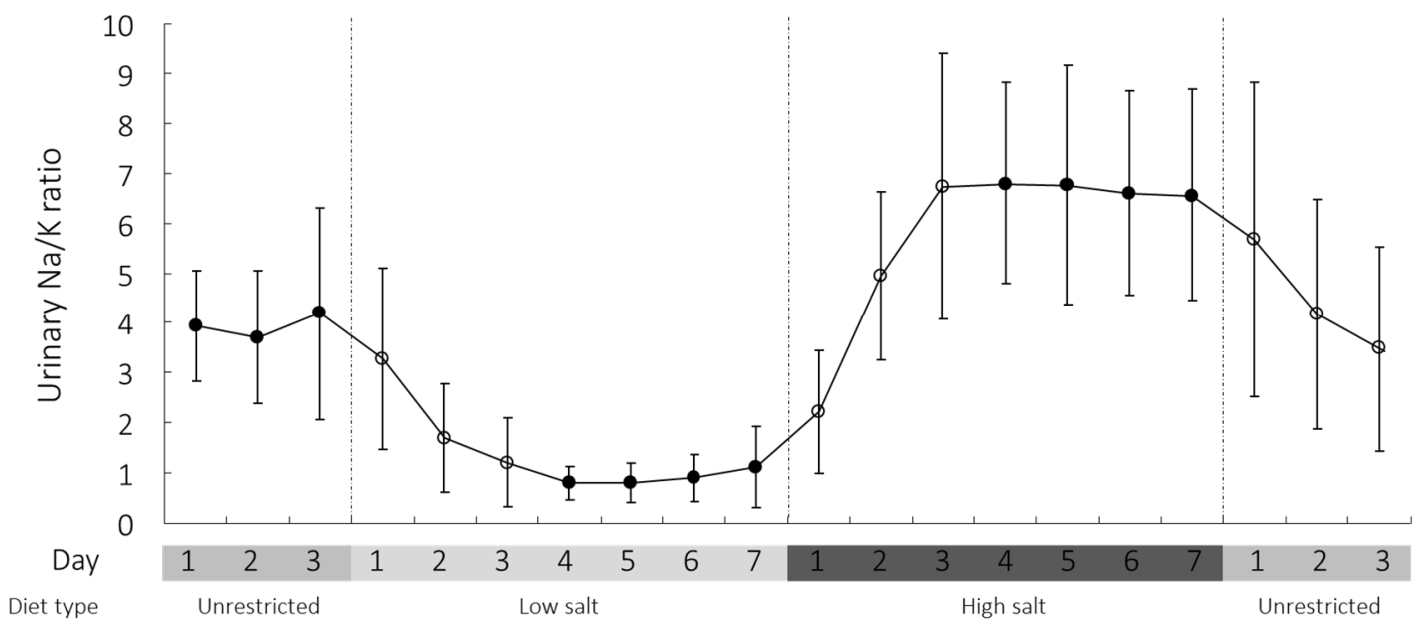

(b)

Figure 1. Time-dependent changes in urinary $\mathrm{Na} / \mathrm{K}$ ratio $(\mathrm{UNaK})$ during unrestricted, low-salt ( $3 \mathrm{~g} \mathrm{NaCl} /$ day), and high-salt ( $20 \mathrm{~g} \mathrm{NaCl}$ /day) diet periods measured by the device. (a) Individual trends and (b) group average throughout the study.

\subsection{Validation of Daily Mean Spot Urine Na/K Ratio for Estimating 24-h Urine Na/K Ratio}

The individual daily means of the spot urine $\mathrm{Na} / \mathrm{K}$ ratio for the last three days of each diet period correlated well with the 24-h urine $\mathrm{Na} / \mathrm{K}$ ratio of the last day of each diet period (Figure 2). For the daily mean spot urine $\mathrm{Na} / \mathrm{K}$ ratio determined on the last day of each diet period, the bias estimate, defined as the difference between the $\mathrm{Na} / \mathrm{K}$ ratios of the 24-h and spot urine collections, was 0.13 , whereas the $95 \%$ limit of the difference ranged from -2.96 to 3.21 , according to the Bland-Altman method (Figure 2). The voiding frequency ranged from three to eight times per day (mean: 4.0 and 5.0 times per day during the LS and HS diet periods, respectively) in this study. Figure S2 shows the correlations between the 24-h urine $\mathrm{Na} / \mathrm{K}$ ratio on the last day and the means of different numbers of randomly selected spot urine $\mathrm{Na} / \mathrm{K}$ ratios during the last three days of each diet period. The correlation coefficient ranged from 0.74 to 0.88 , the bias ranged from 0.16 to 0.39 , and the $95 \%$ lower and upper limits of difference ranged from -0.45 to -0.19 and 0.72 to 1.1 , respectively, among these combinations. The correlation between the mean $\mathrm{Na} / \mathrm{K}$ ratio of three to seven spot urine samples and the 24- $\mathrm{h}$ urine collection remained high, and their agreement was good (Figure S2). 


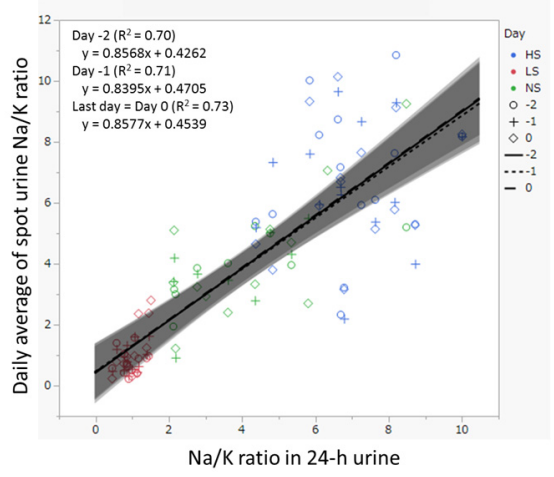

(a)

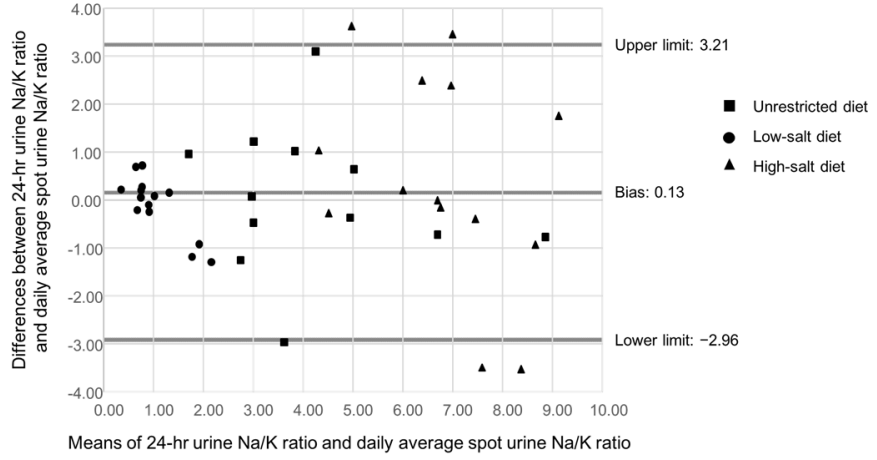

(b)

Figure 2. Correlation and agreement analyses between individual daily means of the spot urine $\mathrm{Na} / \mathrm{K}$ ratio and 24-h urine Na/K ratio: (a) Spearman's correlation between the 24-h urine Na/K ratio during the last day of each diet period and individual daily means of the spot urine $\mathrm{Na} / \mathrm{K}$ ratio of the last three days of each diet period. Data points from unrestricted (NS), low-salt (LS), and high-salt (HS) diet periods are shown in green, blue, and red, respectively. The regression lines calculated for the last day (0), the day before (-1), and two days before the last day $(-2)$ are shown with $95 \%$ confidence interval in gray areas. (b) Bland-Altman plot of the 24-h urine $\mathrm{Na} / \mathrm{K}$ ratio and daily means of the spot urine $\mathrm{Na} / \mathrm{K}$ ratio on the last day of each diet period.

\section{Discussion}

The relationship between the urinary $\mathrm{Na} / \mathrm{K}$ ratio and dietary $\mathrm{Na} / \mathrm{K}$ ratio, $\mathrm{Na}$, and $\mathrm{K}$ levels has been unclear. Frequent monitoring of the urinary $\mathrm{Na} / \mathrm{K}$ ratio during acute changes in salt intake has not been reported previously. This nonparallel, experimental dietary study demonstrated the relationship between standardized dietary $\mathrm{Na}$ and $\mathrm{K}$ intake levels and the corresponding urinary $\mathrm{Na} / \mathrm{K}$ ratio among healthy volunteers. Association studies have demonstrated the benefits of monitoring the $\mathrm{Na} / \mathrm{K}$ ratio to assess Na reduction and $\mathrm{K}$ increase in relation to BP and CVD risks, as compared with monitoring $\mathrm{Na}$ and $\mathrm{K}$ levels separately. However, the urinary and dietary $\mathrm{Na} / \mathrm{K}$ ratio levels used for assessing risk scores differed among these previous studies due to the percentage of diet reflected in the urine [25-27,36,37]. In the present study, the urinary $\mathrm{Na} / \mathrm{K}$ ratio tracked the changes in dietary $\mathrm{Na}$ intake; changes were reflected in the urinary $\mathrm{Na} / \mathrm{K}$ ratio within approximately three days under standardized dietary conditions. Furthermore, the daily means of the urinary $\mathrm{Na} / \mathrm{K}$ ratio correlated well with those of the dietary $\mathrm{Na} / \mathrm{K}$ ratio, and the former was approximately 1.3 times the value of the latter.

Use of formulas to estimate 24-h urinary Na excretion from a single spot urine sample depends on other parameters, such as body weight and creatinine clearance [15-17], and may be biased [18,19], whereas the $\mathrm{Na} / \mathrm{K}$ ratio is independent of both creatinine excretion and body weight, and is also unbiased [26]. Repeated spot urine $\mathrm{Na} / \mathrm{K}$ ratios may therefore be a useful and practical means for obtaining individual values of the urinary $\mathrm{Na} / \mathrm{K}$ ratio $[29,30]$. The spot urine $\mathrm{Na} / \mathrm{K}$ ratio showed higher correlations and better agreements with 24-h urine values than the $\mathrm{Na}$ or $\mathrm{K}$ level alone [28-30], especially when using repeated spot urine measurements [29,30]. The results of the agreement and correlation analyses of four to seven repeated measurements of the spot urine $\mathrm{Na} / \mathrm{K}$ ratio were similar to those of one to two-day 24 -h urine $\mathrm{Na} / \mathrm{K}$ ratios, when compared with the gold standard seven-day 24-h urine $\mathrm{Na} / \mathrm{K}$ ratio $[29,30]$.

In this study, we primarily used the daily mean of the spot urine $\mathrm{Na} / \mathrm{K}$ ratio, but we also examined the use of different repetitions of spot urine sampling to determine their agreement with the 24-h urine $\mathrm{Na} / \mathrm{K}$ ratio under standardized and unrestricted dietary conditions. Increasing the number of random spot urine $\mathrm{Na} / \mathrm{K}$ ratio samples is known to improve the correlation with the seven-day 24-h urine $\mathrm{Na} / \mathrm{K}$ ratio $[29,30]$, as confirmed by our findings, although the level of agreement in our study 
was slightly less than that reported previously. This may be because only a single 24-h urine sample collection was performed for each dietary condition in the present study. However, the correlation data indicated that the mean of multiple spot urine $\mathrm{Na} / \mathrm{K}$ ratios reflected the $24-\mathrm{h} \mathrm{Na} / \mathrm{K}$ ratio well. The daily mean of the spot urine $\mathrm{Na} / \mathrm{K}$ ratio was roughly equivalent to the mean of five random spot urine $\mathrm{Na} / \mathrm{K}$ ratio measurements. This may be explained by voiding frequency. For relatively short-term studies, the daily mean spot urine $\mathrm{Na} / \mathrm{K}$ ratio measured at least four days after a change in diet may serve as a simple substitute for a $24-\mathrm{h}$ urine $\mathrm{Na} / \mathrm{K}$ ratio.

In this regard, a self-monitoring device for the urinary $\mathrm{Na} / \mathrm{K}$ ratio measurement, which provides prompt on-site feedback, has been evaluated with a view to supporting an individual approach for $\mathrm{Na}$ reduction and $\mathrm{K}$ increase [31]. Repeated measurement of the spot urine $\mathrm{Na} / \mathrm{K}$ ratio may be a low-burden method for monitoring adherence to World Health Organization (WHO) guidelines on $\mathrm{Na}$ and $\mathrm{K}$ intake. However, interpretation of the individual estimate obtained through the repeated spot urine $\mathrm{Na} / \mathrm{K}$ ratio measurement is difficult, because the urinary $\mathrm{Na} / \mathrm{K}$ ratio corresponding to the dietary $\mathrm{Na}$ and $\mathrm{K}$ intake has not yet been reported. Moreover, a formally recommended cutoff value for this ratio has not been established to date. Our findings provide a basis for $\mathrm{Na} / \mathrm{K}$ monitoring, which is a prerequisite for setting such goals.

Rakova et al. have demonstrated that individual urinary Na excretion fluctuated under controlled dietary conditions, which was similar to the results of our study [14]. However, the amount of dietary salt intake correlated well with the group mean 24-h urinary $\mathrm{Na} / \mathrm{K}$ ratio, based on a 24-h sample collected during the last day of each period, and the urinary $\mathrm{Na} / \mathrm{K}$ ratio obtained by determining the daily mean of repetitive spot urine $\mathrm{Na} / \mathrm{K}$ ratio measurements at least three days after changing the standardized diet. Thus, the single-day 24-h urine collection on the last day of LS and HS diet periods reasonably represented the group estimate of $\mathrm{Na}$ intake during these periods, as the day-to-day variation in Na excretion was minimized by means of the standardized diets. Additionally, the urinary $\mathrm{Na} / \mathrm{K}$ ratio is known to show diurnal variation [38]. Thus, daily repetitive spot urine $\mathrm{Na} / \mathrm{K}$ ratio sampling may have corrected the effect of diurnal variation and therefore show a good association with dietary salt intake and the $24-\mathrm{h}$ urine $\mathrm{Na} / \mathrm{K}$ ratio under controlled dietary conditions.

We determined the urinary $\mathrm{Na} / \mathrm{K}$ molar ratio corresponding to the $\mathrm{Na}$ and $\mathrm{K}$ intake using our standardized diets. The dietary $\mathrm{Na} / \mathrm{K}$ molar ratios in this study were designed to be 0.80 and 5.3 on the $\mathrm{LS}(\mathrm{NaCl}, 3 \mathrm{~g} /$ day; K, $2.5 \mathrm{~g} /$ day; $\mathrm{Na} / \mathrm{K}$ molar ratio = 51.3/64.1 mmol/mmol) and $\mathrm{HS}(\mathrm{NaCl}, 20 \mathrm{~g} / \mathrm{day}$; $\mathrm{K}, 2.5 \mathrm{~g} /$ day; $\mathrm{Na} / \mathrm{K}$ molar ratio $=341.9 / 64.1 \mathrm{mmol} / \mathrm{mmol}$ ) diets. Previous reports have indicated that $80-95 \%$ of dietary $\mathrm{Na}[13,39-42]$ and $63-77 \%$ of dietary $\mathrm{K}[13,40,41]$ is excreted in the urine. Thus, if $90 \%$ and $70 \%$ of dietary $\mathrm{Na}$ and $\mathrm{K}$, respectively, are excreted in the urine, the urinary $\mathrm{Na} / \mathrm{K}$ ratio would be 1.3 times the dietary $\mathrm{Na} / \mathrm{K}$ ratio, which indicates that the theoretical urinary $\mathrm{Na} / \mathrm{K}$ molar ratio should be 1.0 and 6.8 on the LS and HS diets, respectively, in the present study. The actual group averages of the 24-h urine $\mathrm{Na} / \mathrm{K}$ molar ratio were 1.0 and 6.9 on the LS and HS diets, respectively; the urinary $\mathrm{Na} / \mathrm{K}$ molar ratio obtained as the daily mean of spot urine $\mathrm{Na} / \mathrm{K}$ ratios were 1.1 and 6.6, which were close to these theoretical values. However, the $24-\mathrm{h}$ urine $\mathrm{Na}$ and $\mathrm{K}$ excretions were $58-81 \%$ and $48-66 \%$, respectively, of the designed dietary content during the LS and HS diet periods.

As shown in Table 2, the component of the urinary $\mathrm{Na} / \mathrm{K}$ ratio that showed the predominant change was the amount of $\mathrm{Na}$ excreted, which reflected $\mathrm{NaCl}$ consumption. Although there was a significant increase in urinary $\mathrm{K}$ excretion during the HS diet period, which may have resulted from increased $\mathrm{Na}$ delivery to the distal tubules of the kidney [43,44], the change in $\mathrm{K}$ was much smaller than that in $\mathrm{Na}$, and $\mathrm{K}$ excretion did not differ between the HS and the NS diet periods. Moreover, a recent self-monitoring intervention study on lowering the urinary $\mathrm{Na} / \mathrm{K}$ ratio mainly resulted in Na reduction, with little change observed in $\mathrm{K}$ [31]. These findings suggest that the change in urinary $\mathrm{Na} / \mathrm{K}$ ratio in real world conditions (with $\mathrm{Na}$ and $\mathrm{K}$ intake levels close to the average of the general population) would be mainly due to changes in $\mathrm{Na}$, and would be relatively independent of K. However, these assumptions may not be applicable to individuals with an extreme $\mathrm{K}$ intake or to patients with kidney diseases. Furthermore, a decrease in urinary Na excretion during the LS 
diet period may have been due to sustained extra-renal Na loss, and the lower-than-expected $\mathrm{Na}$ and $\mathrm{K}$ excretion seen throughout the study may have been due to the loss of $\mathrm{Na}$ in sweat, as some participants participated in sports during the study, in addition to possible incomplete urine collection. Considering that 24-h urine $\mathrm{Na}$ and $\mathrm{K}$ measurements may result in $\mathrm{Na}$ and $\mathrm{K}$ intake underestimations due to incomplete collections [10], the use of the $\mathrm{Na} / \mathrm{K}$ ratio is more advantageous than separate $\mathrm{Na}$ or K excretion assessments, because it is resistant to systematic errors related to urine volume. The finding that the rate of $\mathrm{K}$ excretion was lower than that of $\mathrm{Na}$ excretion in our study may also be explained by a relative $\mathrm{K}$ deficiency in our study participants and due to racial differences in the $\mathrm{K}$ balance [40].

Changes associated with salt intake were appropriately observed in this study, such as those in urine volume, voiding frequency, serum creatinine levels, hematocrit, plasma aldosterone concentrations, and plasma renin activity. No significant changes in blood pressure were observed in our study, which may be due to the inclusion of young normotensive participants and a short salt-loading duration. The normotensive population has been reported to display a lower percentage of blood pressure salt-sensitivity than the hypertensive population [45].

Dietary $\mathrm{NaCl}$ intake may be roughly estimated from the urinary $\mathrm{Na} / \mathrm{K}$ ratio by examining the population mean $24-\mathrm{h}$ urine $\mathrm{Na} / \mathrm{K}$ molar ratio and the population mean $24-\mathrm{h}$ urine salt $(\mathrm{NaCl})(\mathrm{g} /$ day $)$ concentration [30]. In this study, the ratio of dietary $\mathrm{NaCl}$ (g/day) to urinary $\mathrm{Na} / \mathrm{K}$ molar ratio was approximately 3 , in different dietary conditions; the group mean $24-\mathrm{h}$ urine $\mathrm{Na} / \mathrm{K}$ molar ratio during LS and HS diet periods were 1.0 and 6.9, when the group mean salt intake was 3 (g/day) and 20 (g/day), respectively. Findings from the INTERMAP (International study of macro- and micro-nutrients and blood pressure) study showed that the population mean dietary salt intake of 11.8 (g/day) corresponded to a population mean 24-h urine Na/K molar ratio of 4.3, in four Japanese cohort centers [32]. Thus, a rough estimate of the group mean salt intake (g/day) may be taken as being approximately three times the group mean 24-h urinary $\mathrm{Na} / \mathrm{K}$ molar ratio. Thus, considering that the group mean urinary $\mathrm{Na} / \mathrm{K}$ molar ratio during the NS diet period was 4.2 , the group mean salt intake may have ranged from 12 to $13 \mathrm{~g} /$ day.

WHO reports suggest that guideline-targeted $\mathrm{Na}$ and $\mathrm{K}$ intake levels would yield a $\mathrm{Na} / \mathrm{K}$ ratio of approximately $1.0[46,47]$. Extrapolating from the present study, an average urinary $\mathrm{Na} / \mathrm{K}$ molar ratio of approximately 1 would correspond to a dietary salt intake of $3 \mathrm{~g}$ per day, rather than $5 \mathrm{~g}$ per day. However, given that the K intake level during the LS period in our study was lower than that recommended by the WHO guideline, the dietary salt intake level needed to satisfy the $\mathrm{Na} / \mathrm{K}$ ratio of 1 should be lower than the Na level recommended by the WHO guideline. This phenomenon may occur in a real-world setting. During the LS diet period, more than $70 \%$ and $90 \%$ of spot urine $\mathrm{Na} / \mathrm{K}$ molar ratio measurements were $\leq 1.0$ and $\leq 2.0$, respectively. Considering that Cook et al. reported that a $\mathrm{Na} / \mathrm{K}$ molar ratio of between 1 and 2 resulted in the lowest CVD risk [25], a urinary $\mathrm{Na} / \mathrm{K}$ ratio of $<2$ might be a reasonable current goal for most individuals, in terms of lowering BP and reducing CVD risk. Further investigations are needed to explore the possibility that a lower target than that currently aspired to might be optimal.

This study has several limitations. First, the participants were young Japanese individuals, and the sample size was relatively small. Second, it is not known whether the urinary $\mathrm{Na} / \mathrm{K}$ ratio acclimatizes over a longer period after an acute change in diet. Another limitation of the study is that the actual food intake and data collection were dependent on the participants, although we attempted to achieve high-quality 24-h urine collection in this study by monitoring the start and end of the collection period $[10,48]$. However, the urinary excretion-to-dietary intake ratio of electrolytes were somewhat lower than those previously reported [13,14,39-42]. The relatively low $\mathrm{NaCl}$ and $\mathrm{K}$ excretion values and the low urine volume may be partly due to incomplete urine collection, as well as to excess $\mathrm{Na}$ loss in sweat during sports participation. 


\section{Conclusions}

In conclusion, we determined that the group average of the individual daily means of the spot urine $\mathrm{Na} / \mathrm{K}$ ratio tracked the changes in dietary levels of $\mathrm{Na}$. Frequent urinary $\mathrm{Na} / \mathrm{K}$ ratio monitoring may be a useful index of individuals' dietary Na and $\mathrm{K}$ levels, which may help individuals to adhere to appropriate $\mathrm{Na}$ intake amounts, and thereby may contribute to the reduction of cardiovascular complications.

Supplementary Materials: The following are available online at www.mdpi.com/2072-6643/9/9/951/s1. Figure S1: (a) Urinary Na/K ratio monitor (HEU-001F, Omron Healthcare Co., Ltd., Kyoto, Japan); (b) Pearson's correlation coefficient for the urinary $\mathrm{Na} / \mathrm{K}$ ratios measured by the portable urinary $\mathrm{Na} / \mathrm{K}$ ratio monitor (HEU-001F, Omron Healthcare Co., Ltd., Kyoto, Japan) and by a biochemical inspection center (BML Inc., Tokyo, Japan). Figure S2: Correlation between one random spot urine $\mathrm{Na} / \mathrm{K}$ ratio as well as the average of three, five, or seven random spot urine $\mathrm{Na} / \mathrm{K}$ ratios obtained during the last three days of each diet period and the 24-h urine $\mathrm{Na} / \mathrm{K}$ ratio obtained on the last day of each diet period.

Acknowledgments: This study was conducted at Fukushima Medical University in cooperation with the Department of Public Health of Shiga University of Medical Science and Omron Healthcare Co., Ltd. We gratefully acknowledge the excellent technical assistance of Ayumi Haneda. We also thank the dieticians, Fumie Taguchi, Emi Ohashi, and Izumi Ishida, for designing the menus. Satsuki Kurosawa, Yuri Ikeda, Mizuho Yonemoto, and Momoko Nochi participated in the data collection and analysis. This work was supported by a step-up project grant from Fukushima Medical University (MSY), JPS KAKENHI Grant Number 15K21263 (MSY) and NIH grants, HL074940 (RAF) and DK039308 (RAF).

Author Contributions: M.S.Y., T.I., and J.Y. contributed to the design of the study. M.S.Y. and J.Y. participated in the data collection and analysis. M.S.Y., T.I., K.M., H.U., and J.Y. contributed to the drafting of the manuscript. All authors participated in the critical revision of the manuscript and approved the final version of the manuscript for submission.

Conflicts of Interest: Toshiyuki Iwahori is an employee of Omron Healthcare Co., Ltd. Hirotsugu Ueshima serves as a consultant for Omron Healthcare Co., Ltd. Katsuyuki Miura received a research fund from Omron Healthcare Co. Ltd.

\section{References}

1. Adrogué, H.J.; Madias, N.E. Sodium and potassium in the pathogenesis of hypertension. N. Engl. J. Med. 2007, 356, 1966-1978. [CrossRef] [PubMed]

2. Gay, H.C.; Rao, S.G.; Vaccarino, V.; Ali, M.K. Effects of different dietary interventions on blood pressure: Systematic review and meta-analysis of randomized controlled trials. Hypertension 2016, 67, 733-739. [CrossRef] [PubMed]

3. He, F.J.; Li, J.; MacGregor, G.A. Effect of longer term modest salt reduction on blood pressure: Cochrane systematic review and meta-analysis of randomized trials. BMJ 2013, 346, f1325. [CrossRef] [PubMed]

4. Aburto, N.J.; Ziolkovska, A.; Hooper, L.; Elliott, P.; Cappuccio, F.P.; Meerpohl, J.J. Effect of lower sodium intake on health: Systematic review and meta-analyses. BMJ 2013, 346, f1326. [CrossRef] [PubMed]

5. Aburto, N.J.; Hanson, S.; Gutierrez, H.; Hooper, L.; Elliott, P.; Cappuccio, F.P. Effect of increased potassium on cardiovascular risk factors and disease: Systematic review and meta-analyses. BMJ 2013, 346, f1378. [CrossRef] [PubMed]

6. Brown, I.J.; Tzoulaki, I.; Candeias, V.; Elliott, P. Salt intakes around the world: Implications for public health. Int. J. Epidemiol. 2009, 38, 791-813. [CrossRef] [PubMed]

7. Cogswell, M.E.; Zhang, Z.; Carriquiry, A.L.; Gunn, J.P.; Kuklina, E.V.; Saydah, S.H.; Yang, Q.; Moshfegh, A.J. Sodium and potassium intakes among US adults: NHANES 2003-2008. Am. J. Clin. Nutr. 2012, 96, 647-657. [CrossRef] [PubMed]

8. Bernstein, A.M.; Willett, W.C. Trends in 24-h urinary sodium excretion in the United States, 1957-2003: A systematic review. Am. J. Clin. Nutr. 2010, 92, 1172-1180. [CrossRef] [PubMed]

9. Cogswell, M.E.; Mugavero, K.; Bowman, B.A.; Frieden, T.R. Dietary sodium and cardiovascular disease risk-measurement matters. N. Engl. J. Med. 2016, 375, 580-586. [CrossRef] [PubMed]

10. Cobb, L.K.; Anderson, C.A.; Elliott, P.; Hu, F.B.; Liu, K.; Neaton, J.D.; Whelton, P.K.; Woodward, M.; Appel, L.J. American Heart Association Council on Lifestyle and Metabolic Health. Methodological issues in cohort studies that relate sodium intake to cardiovascular disease outcomes: A science advisory from the American Heart Association. Circulation 2014, 129, 1173-1186. [CrossRef] [PubMed] 
11. Liu, K.; Stamler, J. Assessment of sodium intake in epidemiological studies on blood pressure. Ann. Clin. Res. 1984, 16 (Suppl. 43), 49-54. [PubMed]

12. Lerchl, K.; Rakova, N.; Dahlmann, A.; Rauh, M.; Goller, U.; Basner, M.; Dinges, D.F.; Beck, L.; Agureev, A.; Larina, I.; et al. Agreement between 24-hour salt ingestion and sodium excretion in a controlled environment. Hypertension 2015, 66, 850-857. [CrossRef] [PubMed]

13. Kawasaki, T.; Itoh, K.; Uezono, K.; Sasaki, H. A simple method for estimating $24 \mathrm{~h}$ urinary sodium and potassium excretion from second morning voiding urine specimen in adults. Clin. Exp. Pharmacol. Physiol. 1993, 20, 7-14. [CrossRef] [PubMed]

14. Tanaka, T.; Okamura, T.; Miura, K.; Kadowaki, T.; Ueshima, H.; Nakagawa, H.; Hashimoto, T. A simple method to estimate populational 24-h urinary sodium and potassium excretion using a casual urine specimen. J. Hum. Hypertens. 2002, 16, 97-103. [CrossRef] [PubMed]

15. Brown, I.J.; Dyer, A.R.; Chan, Q.; Cogswell, M.E.; Ueshima, H.; Stamler, J.; Elliott, P.; INTERSALT Co-Operative Research Group. Estimating 24-hour urinary sodium excretion from casual urinary sodium concentrations in Western populations: The INTERSALT study. Am. J. Epidemiol. 2013, 177, 1180-1192. [CrossRef] [PubMed]

16. Polonia, J.; Lobo, M.F.; Martins, L.; Pinto, F.; Nazare, J. Estimation of populational 24-h urinary sodium and potassium excretion from spot urine samples: Evaluation of four formulas in a large national representative population. J. Hypertens. 2017, 35, 477-486. [CrossRef] [PubMed]

17. Huang, L.; Crino, M.; Wu, J.H.; Woodward, M.; Barzi, F.; Land, M.A.; McLean, R.; Webster, J.; Enkhtungalag, B.; Neal, B. Mean population salt intake estimated from 24-h urine samples and spot urine samples: A systematic review and meta-analysis. Int. J. Epidemiol. 2016, 45, 239-250. [CrossRef] [PubMed]

18. Iwahori, T.; Miura, K.; Ueshima, H. Time to consider use of the sodium-to-potassium ratio for practical sodium reduction and potassium increase. Nutrients 2017, in press. [CrossRef] [PubMed]

19. INTERSALT Co-operative Research Group. INTERSALT: An international study of electrolyte excretion and blood pressure. Results for 24-hr urinary sodium and potassium excretion. BMJ 1988, 297, 319-328.

20. Stamler, J.; Rose, G.; Stamler, R.; Elliott, P.; Dyer, A.; Marmot, M. INTERSALT study findings. Public health and medical care implications. Hypertension 1989, 14, 570-577. [CrossRef] [PubMed]

21. Tzoulaki, I.; Patel, C.J.; Okamura, T.; Chan, Q.; Brown, I.J.; Miura, K.; Ueshima, H.; Zhao, L.; Van Horn, L.; Daviglus, M.L.; et al. A nutrient-wide association study on blood pressure. Circulation 2012, 126, 2456-2464. [CrossRef] [PubMed]

22. Perez, V.; Chang, E.T. Sodium-to-potassium ratio and blood pressure, hypertension, and related factors. Adv. Nutr. 2014, 5, 712-741. [CrossRef] [PubMed]

23. Cook, N.R.; Obarzanek, E.; Cutler, J.A.; Buring, J.E.; Rexrode, K.M.; Kumanyika, S.K.; Appel, L.J.; Whelton, P.K. Trials of Hypertension Prevention Collaborative Research Group. Joint effects of sodium and potassium intake on subsequent cardiovascular disease: The Trials of Hypertension Prevention follow-up study. Arch. Intern. Med. 2009, 169, 32-40. [CrossRef] [PubMed]

24. Cook, N.R.; Appel, L.J.; Whelton, P.K. Sodium intake and all-cause mortality over 20 years in the Trials of Hypertension Prevention. J. Am. Coll. Cardiol. 2016, 68, 1609-1617. [CrossRef] [PubMed]

25. Cook, N.R.; Cutler, J.A.; Obarzanek, E.; Buring, J.E.; Rexrode, K.M.; Kumanyika, S.K.; Appel, L.J.; Whelton, P.K. Long term effects of dietary sodium reduction on cardiovascular disease outcomes: Observational follow-up of the Trials of Hypertension Prevention (TOHP). BMJ 2007, 334, 885-888. [CrossRef] [PubMed]

26. Iwahori, T.; Miura, K.; Ueshima, H.; Chan, Q.; Dyer, A.R.; Elliott, P.; Stamler, J.; INTERSALT Research Group. Estimating 24-hour urinary sodium/potassium ratio from casual ("spot") urinary sodium/potassium ratio: The INTERSALT Study. Int. J. Epidemiol. 2016, in press. [CrossRef] [PubMed]

27. Iwahori, T.; Ueshima, H.; Miyagawa, N.; Ohgami, N.; Yamashita, H.; Ohkubo, T.; Murakami, Y.; Shiga, T.; Miura, K. Six random samples of casual urine on different days are sufficient to estimate daily sodium/potassium ratio as compared to 7-day 24-h urine collections. Hypertens. Res. 2014, 37, 765-771. [CrossRef] [PubMed]

28. Iwahori, T.; Ueshima, H.; Torii, S.; Saito, Y.; Fujiyoshi, A.; Ohkubo, T.; Miura, K. Four to seven random casual urine specimens are sufficient to estimate 24 -h urinary sodium/potassium ratio in individuals with high blood pressure. J. Hum. Hypertens. 2016, 30, 328-334. [CrossRef] [PubMed] 
29. Iwahori, T.; Ueshima, H.; Ohgami, N.; Yamashita, H.; Miyagawa, N.; Kondo, K.; Torii, S.; Yoshita, K.; Shiga, T.; Ohkubo, T.; et al. Effectiveness of a self-monitoring device for urinary sodium/potassium ratio on dietary improvement in free-living adults: A randomized controlled trial. J. Epidemiol. 2017, in press.

30. Hunter, D. Biochemical indicators of dietary intake. In Nutritional Epidemiology, 2nd ed.; Willet, W., Ed.; Oxford University Press: New York, NY, USA, 1998; pp. 174-243.

31. Stamler, J.; Chan, Q.; INTERSALT Co-operative Research Group. INTERMAP appendix tables. J. Hum. Hypertens. 2003, 17, 665-758. [CrossRef]

32. Ministry of Health, Labour and Welfare. National Nutrition and Health Survey, 2010; Daiichi Shuppan: Tokyo, Japan, 2012.

33. Yatabe, M.S.; Yatabe, J.; Yoneda, M.; Watanabe, T.; Otsuki, M.; Felder, R.A.; Jose, P.A.; Sanada, H. Salt sensitivity is associated with insulin resistance, sympathetic overactivity, and decreased suppression of circulating renin activity in lean patients with essential hypertension. Am. J. Clin. Nutr. 2010, 92, 77-82. [CrossRef] [PubMed]

34. Bland, J.; Altman, D.G. Statistical methods for assessing agreement between two methods of clinical measurement. Lancet 1986, 1, 307-310. [CrossRef]

35. Yang, Q.; Liu, T.; Kuklina, E.V.; Flanders, W.D.; Hong, Y.; Gillespie, C.; Chang, M.H.; Gwinn, M.; Dowling, N.; Khoury, M.J.; et al. Sodium and potassium intake and mortality among US adults: Prospective data from the Third National Health and Nutrition Examination Survey. Arch. Intern. Med. 2011, 171, 1183-1191. [CrossRef] [PubMed]

36. Okayama, A.; Okuda, N.; Miura, K.; Okamura, T.; Hayakawa, T.; Akasaka, H.; Ohnishi, H.; Saitoh, S.; Arai, Y.; Kiyohara, Y.; et al. Dietary sodium-to-potassium ratio as a risk factor for stroke, cardiovascular disease and all-cause mortality in Japan: The NIPPON DATA80 cohort study. BMJ Open. 2016, 6, e011632. [CrossRef] [PubMed]

37. Rakova, N.; Jüttner, K.; Dahlmann, A.; Schröder, A.; Linz, P.; Kopp, C.; Rauh, M.; Goller, U.; Beck, L.; Agureev, A.; et al. Long-term space flight simulation reveals infradian rhythmicity in human $\mathrm{Na}^{+}$balance. Cell. Metab. 2013, 17, 125-131. [CrossRef] [PubMed]

38. Iwahori, T.; Ueshima, H.; Torii, S.; Yoshino, S.; Kondo, K.; Tanaka-Mizuno, S.; Arima, H.; Miura, K. Diurnal variation of urinary sodium-to-potassium ratio in free-living Japanese individuals. Hypertens. Res. 2017. [CrossRef] [PubMed]

39. Pietinen, P.I.; Findley, T.W.; Clausen, J.D.; Finnerty, F.A.; Altschul, A.M. Studies in community nutrition: Estimation of sodium output. Prev. Med. 1976, 5, 400-407. [CrossRef]

40. Voors, A.W.; Dalferes, E.R., Jr.; Frank, G.C.; Aristimuno, G.G.; Berenson, G.S. Relation between ingested potassium and sodium balance in young blacks and whites. Am. J. Clin. Nutr. 1983, 37, 583-594. [PubMed]

41. Clark, A.J.; Mossholder, S. Sodium and potassium intake measurements: Dietary methodology problems. Am. J. Clin. Nutr. 1986, 43, 470-476. [PubMed]

42. Holbrook, J.T.; Patterson, K.Y.; Bodner, J.E.; Douglas, L.W.; Veillon, C.; Kelsay, J.L.; Mertz, W.; Smith, J.C., Jr. Sodium and potassium intake and balance in adults consuming self-selected diets. Am. J. Clin. Nutr. 1984, 40, 786-793. [PubMed]

43. Palmer, B.F.; Clegg, D.J. Physiology and pathophysiology of potassium homeostasis. Adv. Physiol. Educ. 2016, 40, 480-490. [CrossRef] [PubMed]

44. Palmer, B.F. Regulation of potassium homeostasis. Clin. J. Am. Soc. Nephrol. 2015, 10, 1050-1060. [CrossRef] [PubMed]

45. Armando, I.; Villar, V.A.; Jose, P.A. Genomics and pharmacogenomics of salt-sensitive hypertension. Curr. Hypertens. Rev. 2015, 11, 49-56. [CrossRef] [PubMed]

46. World Health Organization. WHO Guideline: Sodium intake for adults and children. In Geneva: World Health Organization (WHO); WHO: Genève, Switzerland, 2012. 
47. World Health Organization. WHO Guideline: Potassium intake for adults and children. In Geneva: World Health Organization (WHO); WHO: Genève, Switzerland, 2012.

48. The INTERSALT Co-operative Research Group. INTERSALT study: An international co-operative study on the relation of blood pressure to electrolyte excretion in populations, I: Design and methods. J. Hypertens. 1986, 4, 781-787.

2017 by the authors. Licensee MDPI, Basel, Switzerland. This article is an open access article distributed under the terms and conditions of the Creative Commons Attribution (CC BY) license (http://creativecommons.org/licenses/by/4.0/). 